
VOLUME 10 NOMOR 4 AGUSTUS 2021

ISSN : 2303-1514 | E-ISSN : 2598-5949

DOI : http://dx.doi.org/10.33578/jpfkip.v10i4.8054 https://primary.ejournal.unri.ac.id/index.php/JPFKIP

\title{
IMPLEMENTING PROJECT BASED LEARNING MODEL TO IMPROVE STUDENTS' CREATIVE THINKING ABILITY IN WATER CYCLE (HYDROLOGY) MATERIAL AT GRADE V ELEMENTARY SCHOOL
}

\author{
Feggy Nazua $^{1^{*}}$, Nur Aisyah ${ }^{2}$ \\ ${ }^{1,2}$ Universitas Sultan Ageng Tirtayasa, Tangerang, Indonesia \\ ${ }^{* 1}$ feggynazua12@gmail.com
}

\section{PENERAPAN MODEL PEMBELAJARAN PROJECT BASED LEARNING TERHADAP KEMAMPUAN BERPIKIR KREATIF PADA MATERI SIKLUS AIR (HIDROLOGI) UNTUK SISWA KELAS V SEKOLAH DASAR}

\begin{tabular}{|c|c|}
\hline ARTICLE HISTORY & ABSTRACT \\
\hline $\begin{array}{l}\text { Submitted: } \\
12 \text { Desember } 2020 \\
12^{\text {th }} \text { December } 2020\end{array}$ & 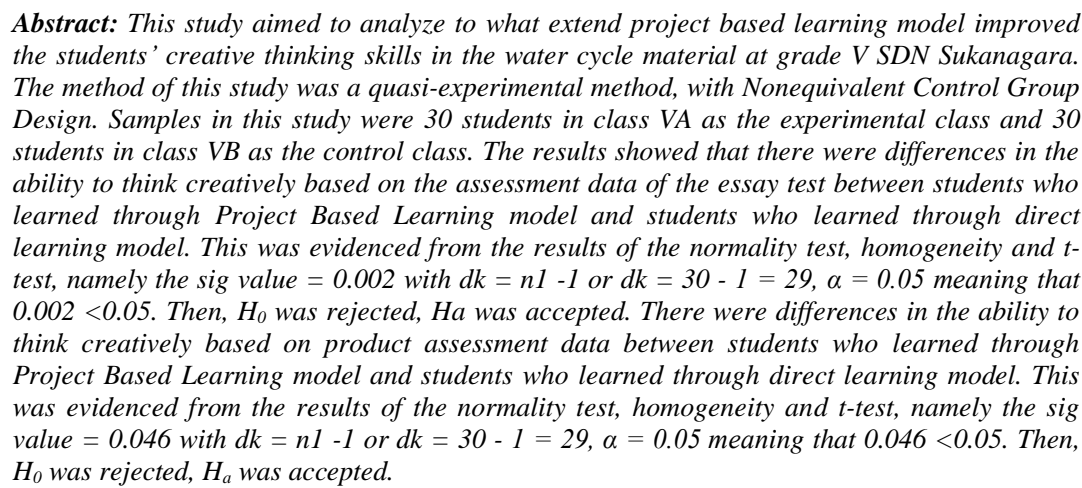 \\
\hline
\end{tabular}

Keyword : PJBL, creative thinking, hydrology

Accepted:

02 Agustus 2021

$02^{\text {th }}$ August 2021

Published:

27 Agustus 2021

$27^{\text {th }}$ August 2021

\begin{abstract}
Abstrak: Penelitian ini bertujuan untuk menganalisis seberapa besar penerapan Model Pembelajaran Project Based Learning terhadap kemampuan berpikir kreatif siswa pada materi siklus air kelas V SDN Sukanagara. Metode penelitian yang digunakan adalah metode kuasi eksperimen, dengan rancangan Nonequivalent Control Grup Design. Sempel dalam penelitian ini adalah siswa kelas VA sebagai kelas eksperimen yang berjumlah 30 peserta didik dan kelas $V B$ sebagai kelas kontrol yang berjumlah 30 peserta didik. Hasil perhitungan peserta didik menunjukkan Terdapat perbedaan kemampuan berpikir kreatif berdasarkan data penilaian tes uraian antara peserta didik yang menggunakan model pembelajaran Project Based Learning dengan siswa yang menggunakan model pembelajaran langsung. Hal ini dibuktikan dari hasil perhitungan dengan menggunakan uji normalitas, homogenitas dan uji-t yaitu nilai sig. 0.002 dengan $d k=n_{1}-1$ atau $d k=30-1=29, \alpha=0.05$ di datapkan bahwa $0.002<0.05$. Maka $H_{0}$ ditolak $H_{a}$ diterima. Terdapat perbedaan kemampuan berpikir kreatif berdasarkan data penialain produk antara peserta didik yang menggunakan model pembelajaran Project Based Learning dengan siswa yang menggunakan model pembelajaran langsung. Hal ini dibuktikan dari hasil perhitungan dengan menggunakan uji normalitas, homogenitas dan uji-t yaitu nilai sig. 0.046 dengan $d k=n_{1}-1$ atau $d k=30-1=29, \alpha=0.05$ di datapkan bahwa $0.046<0.05$. Maka $\mathrm{H}_{0}$ ditolak $\mathrm{H}_{a}$ diterima.
\end{abstract}

Kata Kunci : PJBL, berpikir kreatif, hidrologi

\section{CITATION}

Nazua, F., \& Aisyah, N. (2021). Implementing Project Based Learning Model to Improve Students' Creative Thinking Ability in Water Cycle (Hydrology) Material at Grade V Elementary School. Primary: Jurnal Pendidikan Guru Sekolah Dasar, 10 (4), 949959. DOI: http://dx.doi.org/10.33578/jpfkip.v10i4.8054. 


\section{PENDAHULUAN}

Kurikulum 2013 menuntut guru untuk mengetahui metode pembelajaran Scientific yaitu pembelajaran berpusat pada peserta didik. Metode pembelajaran Scientific mengajak speserta didik untuk belajar secara aktif dan membuat sekolah mengarahkan agar speserta didik berpikir kreatif.

Dalam pembelajaran ini, peserta didik dilatih untuk melakukan analisis terhadap permasalahan, eksplorasi, mengumpulkan informasi, interpretasi, dan penilaian terhadap proyek yang dikerjakan. Dalam modul Implementasi Kurikulum 2013 (2014: 33).

Fokus pembelajaran melibatkan peserta didik dalam investigasi pemecahan masalah, memberi kesempatan peserta didik bekerja secara otonom dalam mengonstruksi pengetahuan mereka sendiri dan mencapai puncak untuk menghasilkan produk nyata (Wena, 2010).

Model pembelajaran PJBL merupakan model pembelajaran yang dapat diterapkan pada mata pelajaran IPA. Melalui model pembelajaran PJBL, kemampuan berpikir kreatif peserta didik dapat meningkat. Keterampilan berpikir kreatif (Creative thingking skill) yang sering juga disebut divergen adalah keterampilan yang bisa menghasilkan jawaban bervariasi dan berbeda dengan yang telah ada sebelumnya (Agusoinal, 2011) mengatakan bahwa kemampuan berpikir kreatif dan teknologi merupakan hal penting dalam masyarakat modern.

Selanjutnya Kosasih (2012 : 1) mengatakan berpikir kreatif merupakan unsur penting dalam perkembangan ilmu pengetahuan, teknologi dan interkasi kegiatan sosial. Seseorang yang berpikir kreatif dapat melakukan pendekatan secara bervariasi dan memiliki bermacam-macam kemungkinan penyelesaian terhadap suatu persoalan.

\section{METODE}

Metode penelitian yang akan digunakan dalam penelitian ini adalah metode Kuasi Eksperimen (Quasi Experimental Design). Menurut (Sugiyono, 2013) Metode eskperimen adalah "metode penelitian yang digunakan untuk mencari pengaruh perlakukan tertentu terhadap yang lain dalam kondisi yang tekendalikan". Dapat disimpulkan metode Ekperimen merupakamn metode yang di buat manipulasi terhadap objek penelitian serta adannya kontrol yang bertujuan untuk menyelidiki ada atau tidaknya sebab-akibat dan hubungan antara sebab-akibat tersebut dengan meberikan sebuah perlakukanperlakuan tertentu pada kelompok eksperimen dan menyediakan kelompok kontrol untuk perbandingan. Desain penelitian yang digunakan berbentuk Nonequivalent Control Grup Design, melibatkan dua kelompok yaitu kelas eksperimen dan kelas kontrol.

\section{Teknik Pengumpulan Data}

(Sugiyono, 2018) dalam penelitian kuantitatif, analisis data merupakan kegiatan setelah data dari seluruh responden atau sumber data lain terkumpul. Kegiatan dalam analisis data adalah mengelompokkan data berdasarkan variabel dan jenis responden, metabulasi data berdasarkan variabel dari seluruh responden, menyajikan data dari tiap variabel yang diteliti, melakukan perhitungan untuk menjawab rumusan masalah, dan melakukan perhitungan untuk menguji hipotesis yang telah diajukan. Untuk penelitian yang tidak merumuskan hipotesis, langkah terakhir tidak dilakukan.

Teknik pengumpulan data merupakan langkah penting dalam suatu penelitian untuk memperoleh data yang diperlukan. Menurut (Sugiyono,2018) Teknik pengumpulan data merupakan langkah yang paling stategis dalam penelitian, karena tujuan utama penelitian adalah mendapatkan data. Tanpa mengetahui teknik pengumpulan data, maka peneliti tidak akan mendapatkan data yang memenuhi standar yang telah digunakan.

Teknik pengumpulan data yang diguankan dalam penelitian ini terdiri dari data utama dan data pendukung. Data utama yaitu tes objektif dan rubrik penilaian produk diorama. Sedangkan data pendukung yaitu 
lembar observasi keterlaksanaan model pembelajaran project based learning.

Instrumen Kemampuan Berpikir Kreatif Siswa Menggunakan Tes Uraian

Definisi Konseptual Instrumen Berpikir Kreatif Siswa

Berpikir kreatif dapat diadaptasikan dari pendekatan Guilford, Willams (Baumen, 1981) beliau mengatakan bahwa untuk mengembangkan kreativitas seseorang maka perlu dilihat aspek kognitif dan aspek afektif. Kemampuan kreativitas yang berhubungan dengan kognitif terdiri dari kelancaran (fluency), keluwesan (flexibility), keaslian (originality) dan elaborasi (elaboration). Sedangkan kemampuan kreativitas yang berhubungan dengan afektif adalah rasa ingin tahu (curiosity), mengambil resiko (courage to take a change), suka tantangan (willingness to challenge an idea), suka berimajinasi atau instuisi (imagination or instuition). Jadi kreativitas adalah kemampuan untuk mencipta atu membuat (to create) dan menghasilkan ide-ide baru yang bermanfaat untuk menyelesaikan masalah. Berpikir kreatif ditandai dengan indikator : kepekaan (sensitivity), kelancaran (fluency), keluwesan (flexibility) dan keaslian (originality).
Definisi Operasional Instrumen Berpikir Kreatif Siswa

Kemampuan berpikir matematika adalah kemampuan dalam IPA yang meliputi empat kemampuan yaitu kelancaran, keluwesan, keaslian dan elaborasi. Kelancaran adalah kemampuan memecahkan masalah IPA secara tepat. Keluwesan adalah kemampuan memecahkan masalah IPA melalui cara yang tidak baku. Keaslian adalah kemampuan memecahkan masalah IPA dengan menggunakan keterampilan, cara atau idenya sendiri dan Elaborasi adalah kemampuan memperluas keterampilan memecahkan masalah, memunculkan masalah baru atau gagasan baru.

Kisi - Kisi Instrumen Kemampuan Berpikir Kreatif

Instrumen yang digunakan untuk mendapatkan data kemampuan berpikir kreatif yaitu tes uraian berjumlah 10 soal. Untuk setiap responden yang menjawab benar satu butir soal diberikan skor 1-3 dan yang menjawab salah diberikan skor 0 . Dengan demikian skor terendah adalah 0 dan skor maksimum adalah 3. Rancangan atau kisi-kisi instrumen tentang penguasaan konsep kimia seperti tabel berikut :

Tabel 1. Kisi - Kisi Instrumen Tes Kemampuan Berpikir Kreatif Siswa

\begin{tabular}{|c|c|c|c|}
\hline No & $\begin{array}{l}\text { Aspek Keterampilan } \\
\text { Berpikir Kreatif }\end{array}$ & Indikator & Nomor Butir Soal \\
\hline 1 & Berpikir lancar (Fluency) & $\begin{array}{l}\text { Menjelaskan pengertian, faktor dan fungsi } \\
\text { siklus air (hidrologi) }\end{array}$ & 1,6 \\
\hline \multirow[t]{2}{*}{2} & Berpikir luwes (Flexibility) & Mengategorikan jenis - jenis siklus air & 4,7 \\
\hline & & $\begin{array}{l}\text { Menganalisis sumber air yang terdapat di } \\
\text { bumi }\end{array}$ & 3,2 , \\
\hline 3 & Berpikir orisinil (Originality) & $\begin{array}{l}\text { Menunjukkan peristiwa evaporasi, } \\
\text { infiltrasi, adveksi, transpirasi, presipitasi, } \\
\text { dan kondensasi }\end{array}$ & 5,8 \\
\hline 4 & $\begin{array}{l}\text { Berpikir } \\
\text { (Evaluation) }\end{array}$ & $\begin{array}{l}\text { Menganalisis kegiatan manusia yang dapat } \\
\text { mempengaruhi proses siklus air }\end{array}$ & 9,10 \\
\hline
\end{tabular}

Validasi Instrumen Kemampuan Berpikir Kreatif Siswa Tingkat Kesukaran

Indeks kesukaran butir tes adalah proporsi peserta yang menjawab benar butir soal (Ahiri, 2008). Untuk mengetahui soalsoal yang mudah, sedang dan sukar dilakukan uji taraf kesukaran. Analisis butir soal dengan 
taraf kesukaran instrumen menggunakan rumus :

$$
\begin{array}{ll} 
& \text { Keterangan : } \\
I \quad=\text { indeks kesukaran }
\end{array}
$$$$
I=\frac{B}{N} \text { (Nana Sujana, 2009) }
$$

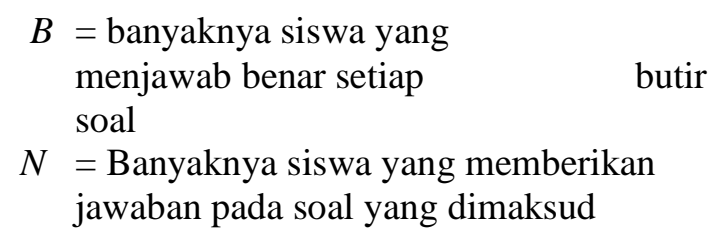

menjawab benar setiap butir

\begin{tabular}{cc} 
Besar nilai $P$ & Interpretasi \\
\hline $0.00-0.30$ & Sukar \\
$0.31-0.70$ & sedang \\
$0.71-1.00$ & mudah \\
\hline
\end{tabular}

(Nana Sujana, 2009:137)

\section{a) Daya Pembeda}

Daya pembeda (discriminating power) atau disingkat DB adalah kemampuan butir soal tes hasil belajar membedakan siswa yang mempunyai kemampuan tinggi dan rendah. Menurut (Purwanto, 2011) DB dapat ditetapkan dengan rumus sebagai berikut :

$$
\begin{gathered}
D=P_{A}-P_{B} \\
P_{A}=\frac{B_{A}}{J A} \text { dan } P_{B}=\frac{B_{B}}{J B}
\end{gathered}
$$

Keterangan :

$$
\begin{aligned}
& D \text { : Indeks daya beda butir soal } \\
& I_{A} \text { : Jumlah siswa tes kelompok } \\
& \text { atas } \\
& I_{B} \quad \text { : Jumlah siswa tes kelompok } \\
& \text { bawah } \\
& B_{A} \quad \text { : Jumlah siswa kelompok } \\
& \text { atas yang menjawab benar } \\
& B_{B} \quad \text { : Jumlah siswa kelompok } \\
& \text { bawah yang menjawab } \\
& \text { benar }
\end{aligned}
$$

$$
\begin{aligned}
& P_{A} \quad: \quad \text { Proporsi peserta kelompok } \\
& \text { atas yang menjawab benar } \\
& P_{B} \quad \text { : Proporsi peserta kelompok } \\
& \text { bawah yang menjawab benar } \\
& N \quad \text { :Jumlah salah satu } \\
& \text { kelompok }
\end{aligned}
$$

\section{b) Validitas Butir Soal Instrumen}

Agar penelitian ini dapat menghasilkan data yang valid (sahih), maka instrumen penelitiannya pun harus valid. Sebuah tes dikatakan valid apabila tes tersebut mengukur apa yang hendak diukur. Untuk pengujian validitas rumus yang digunakan adalah rumus Point Biserial, yaitu:

Nilai Ypbis yang diperoleh dari perhitungan, selanjutnya dikonsultasikan dengan $\mathrm{r}$ tabel product moment. Validitas butir soal ini dilakukan pada 31 siswa responden, maka nilai $r$ tabel pada taraf signifikansi $\alpha=$ $5 \% ; \mathrm{df}=\mathrm{n}-2(\mathrm{n}=$ jumah responden $)$ adalah 0.355 .

Tabel 3. Validitas Butir Soal Tes Kemampuan Berpikir Kreatif Siswa

\begin{tabular}{cccc}
\hline $\begin{array}{c}\text { Butir } \\
\text { Soal }\end{array}$ & $y_{p b i}$ & Ket & Keterangan \\
\hline 1 & 0.58 & Valid & Digunakan \\
2 & 0.55 & Valid & Digunakan \\
3 & 0.56 & Valid & Digunakan \\
4 & 0.09 & Tidak & Tidak \\
& Valid & digunakan
\end{tabular}




\section{PRIMARY: JURNAL PENDIDIKAN GURU SEKOLAH DASAR \\ VOLUME 10 NOMOR 4 AGUSTUS 2021 \\ ISSN : 2303-1514 | E-ISSN : 2598-5949 \\ DOI : http://dx.doi.org/10.33578/jpfkip.v10i4.8054 \\ https://primary.ejournal.unri.ac.id/index.php/JPFKIP}

\begin{tabular}{|c|c|c|c|}
\hline $\begin{array}{l}\text { Butir } \\
\text { Soal }\end{array}$ & $y_{p b i}$ & Ket & Keterangan \\
\hline 5 & 0.36 & Valid & Digunakan \\
\hline 6 & 0.16 & $\begin{array}{l}\text { Tidak } \\
\text { Valid }\end{array}$ & $\begin{array}{c}\text { Tidak } \\
\text { digunakan }\end{array}$ \\
\hline 7 & 0.45 & Valid & Digunakan \\
\hline 8 & 0.43 & Valid & Digunakan \\
\hline 9 & 0.28 & $\begin{array}{l}\text { Tidak } \\
\text { Valid }\end{array}$ & $\begin{array}{c}\text { Tidak } \\
\text { digunakan }\end{array}$ \\
\hline 10 & 0.68 & Valid & Digunakan \\
\hline
\end{tabular}

\section{c) Reliabilitas Butir Soal Instrumen}

Pengujian reliabilitas dilakukan untuk mengetahui kehandalan instrumen apabila diberikan berulang kali pada obyek yang sama. Untuk pengujian reliabilitas yang akan digunakan adalah rumus KR-20, yaitu :

$$
r_{11}=\left(\frac{n}{n-1}\right)\left(\frac{s^{2}-\Sigma p q}{s^{2}}\right) \text { (Arikunto, 2012) }
$$

Keterangan :

$$
\begin{aligned}
& r_{11} \text { : Reliabilitas tes secara keseluruhan. } \\
& n \text { : Banyaknya item. } \\
& S^{2} \text { : Standar deviasi dari tes (standar } \\
& \text { deviasi adalah akar Varians). } \\
& p \text { : Proporsi subjek yang menjawab } \\
& \text { item dengan benar } \\
& q \quad \text { : Poporsi subjek yang menjawab item } \\
& \text { dengan salah }(q=1-p) \text {. } \\
& \sum p q \quad: \text { Jumlah hasil perkalian antara }
\end{aligned}
$$

Untuk mencari varians tiap butir soal menggunakan rumus :

$$
s^{2}=\frac{n \sum x_{i}^{2}-\left(\sum x_{i}\right)^{2}}{n(n-1)} \text { (Sudjana, 2005) }
$$

Dimana :

$s^{2}:$ Jumlah varians skor tiap-tiap item

$\Sigma X_{i}^{2} \quad$ : Jumlah kuadrat item $\mathrm{X}_{\mathrm{i}}$

$\left(\Sigma X_{i}\right)^{2} \quad$ : Jumlah item $X_{\mathrm{i}}$ dikuadratkan

$n \quad$ : Banyaknya sampel uji coba

Jika sudah didapat $\quad r_{11}$ maka dibandingkan dengan $r_{0,6}$ dengan ketentuan: jika $r_{11}>r_{0,6}$ berarti reliabel dan jika $r_{11} \leq r_{0,6}$ berarti tidak reliabel.

Namun ada cara lain yang lebih sederhana dan mudah untuk mencari reliabilitas, yaitu dengan menggunakan interpretasi terhadap koefisien korelasi yang diperoleh. Interpretasi adalah sebagai berikut :

Tabel 4. Interpretasi Nilai $r$

\begin{tabular}{cc}
\hline Besar nilai $r$ & Interpretasi \\
& Tinggi \\
$0.8-1.0$ & Cukup \\
$0.6-0.8$ & Agak Rendah \\
$0.4-0.6$ & Rendah \\
$0.2-0.4$ & Sangat Rendah (tidak \\
$0.0-0.2$ & berkorelasi)
\end{tabular}

Berdasarkan hasil perhitungan reliabilitas tes kemampaun berpikir kreatif siswa menggunakan Microsoft excel diperoleh koefisien reliabilitas $r_{11}=0.608>0.6$;

\section{(Arikunto, 2006)}

sehingga dapat disimpulkan tes kemampuan berpikir kreatif siswa memiliki tingkat reliabilitas yang cukup dan dapat digunakan untuk mengukur data penelitian. 
Kemampuan Berpikir Kreatif

Menggunakan Penilaian Produk

Kemampuan berpikir kreatif diukur menggunakan rubrik penilaian produk diorama. Rubrik ini akan dinilai berdasarkan beberapa indikator-indikator yang terdapat dalam rubrik penilaian. Rubrik penilaian akan dihitung dengan menggunakan rumus sebagai berikut:

Tabel 5. Kriteria Penilaian Produk

\begin{tabular}{cc}
\hline Skor \% & Kriteria \\
\hline $86-100 \%$ & Sangat Baik \\
$76-85 \%$ & Baik \\
$60-75 \%$ & Cukup \\
$55-59 \%$ & Kurang \\
$<54 \%$ & Kurang Sekali \\
\hline \multicolumn{2}{r}{ [Arikunto, 2009] }
\end{tabular}

Untuk uji hipotesis ada tidaknya pengaruh model pembelajaran berbasis proyek terhadap kemampuan berpikir kreatif siswa digunakan Uji T.

\section{HASIL DAN PEMBAHASAN}

Penelitian ini dilakukan di kelas $\mathrm{V}$ SDN Sukanagara Kecamatan Cikupa Kabupaten Tangerang pada semester genap tahun ajaran 2019/2020. Dengan kelas V A yang berjumlah 30 peserta didik sebagai kelas eksperimen dan kelas V B yang berjumlah 30 peserta didik sebagai kelas kontrol. Pada penelitian ini, pengambilan sampel diambil dengan menggunakan teknik Nonprobability Sampling, dengan jumlah sampel sebanyak 61 peserta didik.

Pada kelas eksperimen, pelaksanaan pembelajaran di kelas dilakukan sebanyak 3 kali pertemuan. Dalam kegiatan pembelajaran untuk kelas eksperimen dan kelas kontrol, guru menerapkan model pembelajaran berbasis proyek (Project Best Learning), akan tetapi produk yang dihasilkan berbeda. Pada kelas eksperimen, guru memberikan perlakuan dengan penerapan model pembelajaran berbasis proyek (Project Best Learning) dengan produk yang dihasilkan berupa diorama. Sementara dalam kegiatan pembelajaran di kelas kontrol, guru memberikan perlakuan perlakuan dengan penerapan model pembelajaran berbasis proyek (Project Best Learning) dengan produk yang dihasilkan berupa poster.

Hasil Uji Penerapan Project Based Learning Terhadap Kemampuan Berpikir Kreatif Diukur Dari Tes Objektif

Deskripsi Hasil Pretest Kelas Eksperimen dan Kelas Kontrol

Pada penelitian ini, data tes pretest kemampuan berpikir kreatif didapatkan dari kelas V A dan kelas V B. Sebelumnya peneliti belum menentukan kelompok eksperimen maupun kelas kontrol. Penentuan kelas eksperimen dan kelas kontrol dilakukan setelah mengetahui hasil dari rata - rata pretest kelas V A dan V B.

Tabel 6. Nilai Rata - Rata Hasil Pretest

\begin{tabular}{ccc}
\hline & Kelas V A & Kelas V B \\
\hline Pretest & 30 & 35 \\
\hline
\end{tabular}




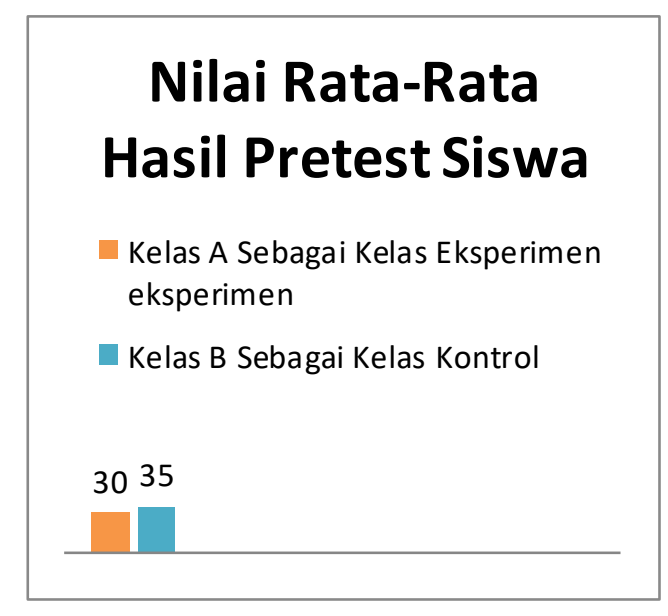

Gambar 1. Nilai Rata - Rata Hasil Pretest

Tabel dan diagram di atas menunjukkan nilai rata - rata hasil pretest, dari hasil pretest yang didapatkan oleh peneliti maka ditetapkan kelas $\mathrm{V}$ A sebagai kelas eksperimen dan kelas V B sebagai kelas kontrol. Hal ini dikarenakan kelas V A mendapatkan nilai rata - rata lebih kecil yaitu sebesar 30 dari kelas V B yang mendapatkan nilai rata - rata sebesar 35 .

\section{Hasil Pengujian Prasyarat Analisis}

Hasil Uji Normalitas

Hasil pengujian uji normalitas pada penelitian ini menggunakan uji Liliefors dengan taraf signifikan dan $\alpha=0.05$ dengan $\mathrm{dk}$ $=30$. Setelah dihitung dengan menggunakan
Liliefors tahap selanjutnya yaitu dengan membandingkan harga $\mathrm{L}_{\text {hitung }}$ dengan $\mathrm{L}_{\text {tabel. }}$ Jika $\mathrm{L}_{\text {hitung }}<\mathrm{L}_{\text {tabel }}$ maka dapat dikatakan bahwa data berdistribusi normal.

\section{Hasil Uji Homogenitas}

Menguji homogenitas varians antara kelas eksperimen dan kelas kontrol dengan menggunakan uji-F. Uji-F digunakan untuk mengetahui sebaran data berasal dari populasi yang homogen atau tidak homogen dengan membandingkan $F_{\text {hitung }}$ dengan $F_{\text {tabel }}$.

Jika $\mathrm{F}_{\text {hitung }}<\mathrm{F}_{\text {tabel }}$ maka data homogen sengkan jika $F_{\text {hitung }}>F_{\text {tabel }}$ maka data tidak homogen. Dengan tarif signifikan $\alpha=0.05$, dk pembilang $=30-1$ dan $\mathrm{dk}$ penyebut $=30-1$.

\section{Tabel 7. Uji Homogenitas Hasil Pretest}

\begin{tabular}{ccccc}
\multirow{2}{*}{$\begin{array}{c}\text { Taraf } \\
\text { signifiikan }\end{array}$} & \multicolumn{2}{c}{$\mathbf{F}$} & \multicolumn{1}{c}{$\mathbf{N}$} & Kesimpulan \\
\cline { 2 - 3 } & Hitung & Tabel & & \\
\hline $\mathbf{0 . 0 5}$ & 1.78 & 1.98 & & \\
& & & Homogen \\
\hline
\end{tabular}

Berdasarkan hasil uji homogenitas yang telah diperoleh dari data hasil pretest maka dat dilihat pada tabel bahwa $\mathrm{F}_{\text {hitung }}<$ $\mathrm{F}_{\text {tabel }}$ dengan nilai 1,78< 1,98 dapat dikatakan bahwa hasil uji homogenitas dari hasil pretest kelas eksperimen dan kelas kontrol adalah homogen.

\section{Deskripsi Hasil Posttest Kelas Eksperimen} dan Kelas Kontrol

Pada penelitian ini, tes posttest diujikan setelah kelas eksperimen mendapatkan perlakuan model pembelajaran Project Based Learning dan kelas kontrol mendapatkan materi pembelajaran dari guru kelasnya untuk mengatahui kemampuan 
Tabel 8. Nilai Rata - Rata Hasil Posttest

\begin{tabular}{ccc}
\hline & Kelas V A & Kelas V B \\
\hline Posttest & 78 & 61 \\
\hline
\end{tabular}

Berdasarkan tabel 8 dan gambar 1 di atas menunjukkan nilai rata - rata posttest yang telah diujikan pada $\mathrm{V}$ A sebagai kelas eksperimen dan V B sebagai kelas kontrol, maka didapatkan nilai rata - rata kelas eksperimen yaitu sebesar 78 dan nilai rata rata kelas kontrol yaitu sebesar 61. Dari data tabel dan diagram di atas diketahui bahwa nilai rata - rata kelas eksperimen lebih besar dari nilai rata - rata kelas kontrol.

Tabel 8. Uji Normalitas Hasil Posttest

\begin{tabular}{ccccc}
\hline $\mathbf{N}$ & Hasil & $\mathbf{L}_{\text {hitung }}$ & $\mathbf{L}_{\text {tabel }}$ & Kesimpulan \\
\hline 30 & Eksperimen & 0.116890214 & 0.173 & Berdistribusi \\
30 & Kontrol & 0.159643901 & & Normal \\
\hline
\end{tabular}

Berdasarkan hasil uji normalitas yang diperoleh dari data hasil pretest dari kelas eksperimen dan kelas kontrol bahwa $\mathrm{L}_{\text {hitung }}<$ $\mathrm{L}_{\text {tabel }}$ dengan nilai $0,1168<0,173$ dan $0,1596<$ 0,173 maka dapat dikatakan bahwa hasil uji normalitas data nilai posttest kelas eksperimen dan kelas kontrol dari penelitian ini adalah data berdistribusi normal.

\section{Hasil Uji Homogenitas}

Menguji homogenitas varians antara kelas eksperimen dan kelas kontrol dengan menggunakan uji-F. Uji-F digunakan untuk mengetahui sebaran data berasal dari populasi yang homogen atau tidak homogen dengan membandingkan $\mathrm{F}_{\text {hitung }}$ dengan $\mathrm{F}_{\text {tabel }}$.

$$
\text { Jika } \mathrm{F}_{\text {hitung }}<\mathrm{F}_{\text {tabel }} \text { maka data }
$$
homogeny sengkan jika $F_{\text {hitung }}>F_{\text {tabel }}$ maka data tidak homogen. Dengan tarif signifikan $\alpha$ $=0,05, \mathrm{dk}$ pembilang $=30-1 \mathrm{dan} \mathrm{dk}$ penyebut $=30-1$. Di bawah ini merupakan uji homogenitas pada hasil posttest yang dilakukan setelah diberikan perlakuan materi pembelajaran untuk kelas eksperimen dan kelas kontrol.

\section{Hasil Pengujian Prasyarat Analisis Hasil Uji Normalitas}

Hasil pengujian uji normalitas pada penelitian ini menggunakan uji Liliefors dengan taraf signifikan dan $\alpha=0,05$ dengan $\mathrm{dk}$ $=30$. Setelah dihitung dengan menggunakan Liliefors tahap selanjutnya yaitu dengan membandingkan harga $\mathrm{L}_{\text {hitung }}$ dengan $\mathrm{L}_{\text {tabel. }}$
Berdasarkan hasil uji homogenitas yang telah diperoleh dari data hasil posttest maka dat dilihat pada tabel bahwa $F_{\text {hitung }}<\mathrm{F}_{\text {tabel }}$ dengan nilai $1,69<1,98$ dapat dikatakan bahwa hasil uji homogenitas dari hasil posttest kelas eksperimen dan kelas kontrol adalah homogen.

\section{Deskripsi Hasil Pretest dan Posttest}

Dalam analisis deskriptif ini data tes kemampuan berpikir kreatif kelas eksperimen yang diberikan perlakuan dengan menggunakan model pembelajaran Project Based Learning, sedangkan kegiatan pembelajaran pada kelas kontrol berjalan apa adanya seperti pembelajaran sehari - hari oleh guru pada mata pelajaran IPA dengan materi (1) pengertian, faktor dan fungsi siklus air (hidrologi); (2) jenis - jenis siklus air; (3) sumber air yang terdapat di bumi; (4) peristiwa evaporasi, infiltrasi, adveksi, transpirasi, presipitasi, dan kondensasi; (5) analisis kegiatan manusia yang dapat mempengaruhi proses siklus air, diperoleh dari hasil pretest dan posttest berupa tes uraian. Soal yang 
diujikan sebanyak 6 butir yang berbentuk essay.

\section{Hasil Uji Penerapan Project Based Learning Terhadap Kemampuan Berpikir Kreatif Diukur Dari Hasil Produk}

Kemampuan berpikir kreatif sesungguhnya adalah suatu kemampuan berpikir yang berawal dari adanya kepekaan terhadap situasi yang dihadapi, bahwa dalam situasi itu teridentifikasi adanya masalah yang ingin atau harus diselesaikan. Hasil yang dimunculkan dalam berpikir kreatif itu sesungguhnya merupakan suatu hal baru bagi siswa yang bersangkutan serta merupakan sesuatu yang berbeda dari biasa yang ia lakukan. Untuk mencapai hal itu seseorang harus melakukan sesuatu terhadap permasalahan yang dihadapi dan tidak tinggal diam saja.

Pada penelitian ini responden pada kelas eksperimen sebanyak 30 siswa yang diberikan perlakuan dengan menggunakan model pembelajaran Project Based Learning, sedangkan pada kelas kontrol sebanyak 30 siswa diberikan pembelajaran langsung. Di bawah ini merupakan data nilai rata - rata penilaian produk dari tiap indikator.

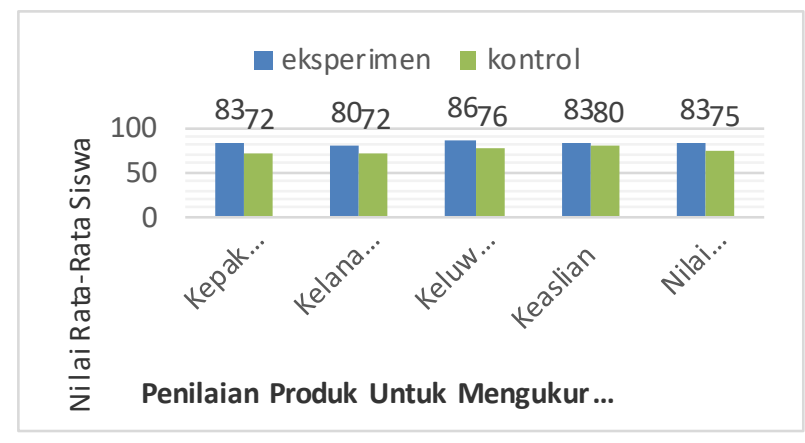

Gambar 2. Nilai Rata- Rata Penilaian Produk Dari Tiap Indikator 
Eksperimen diberi perlakuan dengan model pembelajaran Project Based Learning dan kelas kontrol diberi perlakuan model pembelajaran langsung. Hasil tes akhir (posttest) kemampuan berpikir kreatif kelas eksperimen memperoleh nilai rata - rata sebesar 78 sedangkan untuk kelas kontrol memperolen nilai rata - rata sebesar 61 . Dilihat dari analisis data posttest dengan menggunakan uji-t dua pihak menunjukkan bahwa nilai sig. $0.002 \quad(0.002<0.05)$ maka dapat disimpulkan bahwa terdapat perbedaan antara kemampuan berpikir kreatif kelas eksperimen dan kelas kontrol pada tes akhir (posttest). Kemampuan berpikir kreatif peserta didik pada kelas eksperimen yang diterapkan model pembelajaran Project Based Learning lebih tinggi daripada kemampuan berpikir kreatif peserta didik pada kelas kontrol yang menggunakan model pembelajaran langsung.

Penilaian produk dimana pada kelas eksprimen peserta didik membentuk kelompok membuat media pembelajaran diorama dan pada kelas kontrol membuat poster disetiap kelompoknya. Hasil tes kemampuan berpikir kreatif berdasarkan pada penilaian peroduk,diperoleh nilai rata - rata pada kelas eksperimen adalah 83 dan nilai rata - rata pada kelas kontrol adalah 73. Dilihat dari analisis data penilaian produk dengan menggunakan uji-t dua pihak menunjukkan bahwa nilai sig. $0.046(0.046<0.05)$ maka dapat disimpulkan bahwa terdapat perbedaan antara kemampuan berpikir kreatif kelas eksperimen dan kelas kontrol pada penilaian produk. Berpengaruhnya model pembelajaran berbasis proyek (Project Based Learning) karena beberapa kelebihan yang dimiliki metode tersebut. Diantaranya yaitu dapat mengembangkan keterampilan, aktif selama pembelajaran berlangsung, meneliti permasalahan, dan menciptakan solusi (Wena, 2014: 145).

Oleh sebab itu pada kelas eksperimen yang menggunakan model pembelajaran berbasis proyek (Project Based Learning), kemampuan berpikir kreatif peserta didik lebih besar dibandingkan dengan kelas kontrol yang menggunakan pembelajaran langsung.

\section{KESIMPULAN}

Berdasarkan hasil penelitian dan pembahasan penelitian di SDN Sukanagara diperoleh kesimpulan sebagai berikut:

Terdapat perbedaan kemampuan berpikir kreatif berdasarkan data penilaian tes uraian antara peserta didik yang menggunakan model pembelajaran Project Based Learning dengan siswa yang menggunakan model pembelajaran langsung. Hal ini dibuktikan dari hasil perhitungan dengan menggunakan uji normalitas, homogenitas dan uji-t yaitu nilai sig. 0.002 dengan $\mathrm{dk}=\mathrm{n}_{1}-1$ atau $\mathrm{dk}=30-1=$ $29, \alpha=0,05$ di datapkan bahwa 0,002<0,05. Maka $\mathrm{H}_{0}$ ditolak $\mathrm{H}_{\mathrm{a}}$ diterima.

Terdapat perbedaan kemampuan berpikir kreatif berdasarkan data penialain produk antara peserta didik yang menggunakan model pembelajaran Project Based Learning dengan siswa yang menggunakan model pembelajaran langsung. Hal ini dibuktikan dari hasil perhitungan dengan menggunakan uji normalitas, homogenitas dan uji-t yaitu nilai sig. 0.046 dengan $\mathrm{dk}=\mathrm{n}_{1}-1$ atau $\mathrm{dk}=30-1=$ $29, \alpha=0,05$ di datapkan bahwa $0.046<0.05$. Maka $\mathrm{H}_{0}$ ditolak $\mathrm{H}_{\mathrm{a}}$ diterima.

\section{DAFTAR PUSTAKA}

Aguspinal. (2011). Peningkatan Kemampuan Berpikir Kreatif dan Komunikasi Matematis Siswa Melalui Pendekatan Open-Ended Dengan Strategi Groupto-Group. Tesis. Bandung: UPI.

Ahiri, J. (2008). Metodologi Penelitian. Kendari: Unhalu Press.

Arikunto, S. (2012). Prosedur Penelitian Suatu Pendekatan Praktik. Jakarta: Rineka Cipta.

Kementerian Pendidikan dan Kebudayaan. (2014). Modul Implementasi Kurikulum 2013. Jakarta: Kemendikbud.

Kosasih. (2012). Meningkatkan Berpikir Kreatif Dan Komunikasi Matematis 


\section{PRIMARY: JURNAL PENDIDIKAN GURU SEKOLAH DASAR \\ VOLUME 10 NOMOR 4 AGUSTUS 2021 \\ ISSN : 2303-1514 | E-ISSN : 2598-5949 \\ DOI : http://dx.doi.org/10.33578/jpfkip.v10i4.8054 \\ https://primary.ejournal.unri.ac.id/index.php/JPFKIP}

Siswa Melalui Pendekatan Open-

Ended. Universitas Pendidikan

Indonesia Diakses 25 Desember 2019.

Purwanto. (2011). Evaluasi Hasil Belajar.

Yogyakarta: Pustaka Pelajar.

Sudjana, Nana. (2009). Penilaian Hasil Proses

Belajar Mengajar. Bandung: PT.

Remaja Rosdakarya.

Sugiyono. (2013). Metodologi Penelitian Pendidikan. Bandung: Alfabeta.

Sugiyono. (2018). Metodologi Penelitian Pendidikan. Bandung: Alfabeta.

Wena, M. (2014). Strategi pembelajaran inovatif kontemporer (suatu tinjauan konseptual operasional). PT Bumi Aksara. 